\title{
ВПЛИВ УМОВ ГІПОТЕРМІЧНОГО ЗБЕРІГАННЯ НА МОРФОМЕТРИЧНІ ПОКАЗНИКИ ЕРИТРОЦИТІВ ДОНОРСЬКОЇ КРОВІ
}

\author{
Бортнік Г. А. \\ ДУ «Інститут гематології та трансфузіологї НАМН України», \\ Київ, Украӥна
}

Резюме

Вступ. Відомо, що гіпотермічне зберігання еритроцитів може негативно впливати на широкий спектр функиій циих клітин, щзо суттєво знижує якість еритрочитвмісних компонентів (ЕВК) донорської периферичної крові в цілому.

Мета. Вивчення морфометричних показників еритроцитів в процесі гіпотермічного зберігання ЕВК донорської периферичної крові.

Матеріали і методи. Площу еритроцитів визначали в 30 зразках ЕВК донорської периферичної крові, пофарбованих за Папенгеймом, при світловій мікроскопії з комп'ютерним аналізом зображень. Одночасно оцінювалась форма еритроцитів. При визначення площі еритроцитів донорської крові були використані вбудовані функиії вільно поширюваного програмного забезпечення IтаяеЈ. Досліджували EВК, виготовлені за стандартною методикою з периферичної крові 30 здорових донорів, щчо заготовлена на консервантах, котрі застосовуються в закладах Служби крові Украӥни. Для аналізу даних використовували парний t-критерій Стьюдента для залежних вибірок.

Результати. До VI тижня зберігання спостерігалась статистично незначуща тенденція до зменшення площчі еритрочитів. На останніх етапах зберігання (VIIVIII) відбулась відносна стабілізація показника, щяо досліджувався до параметрів, котрі спостерігались на початку зберігання. При порівнянні зразків ЕВК, що зберігались на консерванті CPD зі зразками на СРDA-1, не виявлено статистичної достовірності між змінами, щчо відбувались на різних етапах зберігання у зазначених консервантах. Під час зберігання ЕВК донорської крові відбуваються значні зміни в морфологї еритроцитів. Мікроскопічне дослідження мазків крові протягом 49 діб зберігання показало зміни форми від нормальних дискоцитів до ехіноцитів і сфероцитів. У дослідженні не спостерігалося значних змін у формі еритроцитів протягом першого тижня зберігання, оскільки нормальні дискочити домінували. На третьому тижні зберігання ми спостерігали значне збільшення кількості ехіночитів в обох зразках. Максимальні зміна форми еритрочитів спостерігалася за останніх тижнях зберігання. На останньому, восьмому етапі, відбулось значне збільшення кількості сфероцитів, але в консерванті СРDA-1 таких клітин було менше, ніж в розчині з консервантом 
CPD. Можливо, такі відмінності можна пояснити наявністю в консерванті СРDА-1 аденіну, котрий є складовою АТФ, оскільки загальновідомо, щуо утворення патологічних форм еритроцитів пов'язане з характерним для консервованих трансфузійних ЕВК збільшенням $р H$, зниженням запасів АТФ.

Висновки. В процесі гіпотермічного зберігання еритроцитвмісних компонентів донорської периферичної крові достовірної різниці в змінах площ еритроцитів не виявлено. Під час гіпотермічного зберігання еритроцитвмісних компонентів протягом 49 діб у консервуючих розчинах CPDA-1 та CPD відбуваються значні зміни форм еритроцитів з нормальних дискоцитів до сфероцитів. Консервуючий розчин, щуо містив у своєму складі аденін, завдає менше негативного впливу на ЕВК під час їхнього зберігання.

Ключові слова: гіпотермічне зберігання, компоненти донорської крові, еритрочити, морфометричні показники.

Фінансування: дослідження не мало спонсорської підтримки.

\title{
INFLUENCE OF HYPOTHERMIC STORAGE CONDITIONS ON MORPHOMETRIC PARAMETERS OF ERYTHROCYTES OF THE DONATED BLOOD
}

\author{
Bortnik H. A. \\ SI «Institute of Haematology and Transfusiology of NAMS of Ukraine», \\ Kyiv, Ukraine
}

\begin{abstract}
Introduction. Hypothermic storage of red blood cells (RBCs) is known to adversely affect a wide range of functions of these cells that significantly reduces the quality of RBC components of donor peripheral blood as a whole.

Aim. The study of RBCs morphometric parameters in the process of hypothermic storage of RBC components of donated blood.

Materials and methods. RBCs size was determined in Pappenheim-stained smears by light microscopy with computer image analysis. The built-in functions of the freely distributed ImageJ software were used to determine the area of RBCs in the donated blood. RBC components, made according to the standard method from peripheral blood of healthy donors, prepared on preservatives used in the Blood Service of Ukraine, were examined. Student's paired t-test for dependent samples was used to analyze the data.

Results. By week VI of storage, there was a statistically insignificant tendency to decrease the area of RBCs. In the last stages of storage (VII-VIII), there was a relative stabilization of the indicator under study to the parameters observed at the beginning. Comparing the RBC examples stored on the CPD preservative with the samples on the $C P D A-1$, found no statistical reliability between the changes that occurred at different stages of storage in these preservatives. During the storage of RBC components of
\end{abstract}


donor blood, there were significant changes in the morphology of the RBCs. Microscopic examination of blood smears during 49 days of storage showed shape changes, from normal discocytes to echinocytes, and spherocytes. The study did not show notable changes in RBCs shape during the first week of storage as normal discocytes dominated. In week III of storage, we observed a remarkable increase in the number of echinocytes in both samples. The maximum change of RBCs shape was observed during last weeks. In the last, eighth stage, there was an outstanding growth of spherocytes, but in the preservative CPDA-1, there were fewer such cells than in the solution with the preservative CPD. Perhaps these differences can be explained by the presence of adenine in the preservative CPDA-1, which is a component of ATP. It is well known that the formation of pathological forms of RBCs is associated with $\mathrm{pH}$ increase and ATP decrease appropriate for preserved transfused $R B C$ components.

Conclusion. The obtained results showed that during 49-days of hypothermic storage of $R B C$ components in the preservative solutions $C P D A-1$ and $C P D$, significant changes in $R B C s$ shape from normal discocytes to spherocytes took place.

The preservative solution containing adenine had a less negative effect on $R B C$ components during their storage.

Keywords: hypothermic storage, donor blood components, red blood cells, morphometric parameters.

\section{Вступ}

Зміна фізико-хімічних параметрів і фізіологічних властивостей клітин під впливом різних речовин і умов навколишнього середовища завжди супроводжується зміною їх морфометричних характеристик. Водночас часто відбувається підвищення або зниження чутливості клітин до дії різних стресових чинників.

Відомо, що гіпотермічне зберігання еритроцитів може негативно впливати на широкий спектр функцій цих клітин, що суттєво знижує якість еритроцитвмісних компонентів (ЕВК) донорської периферичної крові в цілому. Такі зміни виникають як на ранніх стадіях зберігання (протягом перших 7 днів), так і пізніше [1]. До сьогодні немає чіткого розуміння, що відбувається 3 пошкодженими еритроцитами після їхнього переливання. Дослідження демонструють, що частина клітин (до $10 \%$ еритроцитів, що мають високий ступінь пошкодження) видаляється з кровотоку відразу ж після переливання. Решта клітин відновлюють свою функціональність в організмі реципієнта [2].

Оскільки до основних показників стану донорських еритроцитів відносяться їхні морфологічні характеристики, метою роботи було вивчення морфометричного показника - площі еритроцитів в процесі гіпотермічного зберігання ЕВК донорської периферичної крові. 


\section{Матеріали і методи}

Морфометричний показник - площу еритроцитів визначали в мазках периферичної крові, пофарбованих за Папенгеймом, при світловій мікроскопії з комп'ютерним аналізом зображень. Використовували світловий мікроскоп Leica DME (Німеччина), оснащений мікрофотонасадкою з 8-ми мегапіксельною цифровою фотокамерою CanonPowerShot S80. Поля зору, що містять еритроцити, фотографували через об'єктив 3 масляною імерсією кратністю 100 (при загальному збільшенні ×1000). Отримані цифрові мікрофотографії зберігали у файлах формату JPEG. Параметри зйомки та кольорова корекція встановлювались автоматично. При визначення площі еритроцитів донорської крові були використані вбудовані функції вільно поширюваного програмного забезпечення ImageJ (Image Processing and Data Analysis in Java), що використовується для роботи з графічними файлами при біомедичних дослідженнях. Програмне забезпечення ImageJ створене співробітниками National Institutes of Healthi розповсюджується без ліцензійних обмежень як суспільне надбання [3].

Досліджували ЕВК, виготовлені за стандартною методикою з периферичної крові 30 здорових донорів, заготовленої на консервантах CPDA-1 (склад: Цитрат-Фосфат-Декстроза-Аденін-1) - 15 зразків та CPD (склад: Цитрат-Фосфат-Декстроза) - 15 зразків з ресуспендуючим розчином SAGM (склад: Натрію хлорид-Аденін-Глюкоза-Маніт). Аліквоти зберігали в умовах гіпотермії (температура $(2-6)^{\circ} \mathrm{C}$ ) та досліджували на $1,8,15$, 21, 28, 36, 42 та 49-у добу (послідовно I-VIII етапи спостереження). Вивчали розмірну стабільність еритроцитів в залежності від умов і термінів зберігання. Аналіз цифрових зображень еритроцитів представляли у формі двомірного масиву точок (пікселів). Площу фігури вирахували як рівну сумі пікселів нульової і близької до нульової яскравості. В кожному зразку крові аналізували від 100 до 180 площинних розмірів еритроцитів. При цьому вираховували середне арифметичне значення площ еритроцитів. Одночасно оцінювалась форма еритроцитів.

Для аналізу даних використовували парний t-критерій Стьюдента для залежних вибірок.

\section{Результати та їх обговорення}

В таблиці 1 наведені показники площі еритроцитів на етапах гіпотезмічного зберігання ЕВК донорської крові, стабілізованих двома стандартними розчинами, що застосовуються у Службі крові України.

Наведені в таблиці дані свідчать, що до VI тижня зберігання спостерігалась статистично незначуща тенденція до зменшення площі 
еритроцитів. На останніх етапах зберігання (VII-VIII) відбулась відносна стабілізація показника, що досліджувався до параметрів, котрі спостерігались на початку зберігання.

\section{Таблиця 1. Площа еритроцитів" на етапах зберігання з використанням різних консервантів (M \pm m)}

\begin{tabular}{|c|c|c|c|}
\hline \multirow{2}{*}{ ЕтапI } & \multicolumn{2}{|c|}{ Консервант } & \multirow{2}{*}{ p } \\
\cline { 2 - 3 } & $\mathbf{n = 1 5}$ & $\begin{array}{c}\text { CPDA-1 } \\
\mathbf{n = 1 5}\end{array}$ & \\
\hline I & $7261,02 \pm 631,90$ & $6677,34 \pm 1020,36$ & $>0,05$ \\
\hline II & $6933,53 \pm 849,89$ & $7000,98 \pm 848,63$ & $>0,05$ \\
\hline III & $6468,25 \pm 823,54$ & $6659,13 \pm 632,07$ & $>0,05$ \\
\hline IV & $6530,69 \pm 969,21$ & $6308,98 \pm 483,40$ & $>0,05$ \\
\hline V & $6395,26 \pm 637,32$ & $6980,59 \pm 1358,93$ & $>0,05$ \\
\hline VI & $6543,46 \pm 952,40$ & $6503,23 \pm 1079,40$ & $>0,05$ \\
\hline VII & $6936,35 \pm 1050,28$ & $6678,86 \pm 995,62$ & $>0,05$ \\
\hline VIII & $7221,25 \pm 875,70$ & $7455,56 \pm 1136,82^{2}$ & $>0,05$ \\
\hline
\end{tabular}

Примітка: ${ }^{*}$ - виражена у пікселях; ${ }^{1}$ - статистичних відмінностей між зразками в консерванті CPD на I i VIII етапах не виявлено; ${ }^{2}$ - статистичних відмінностей між зразками в консерванті CPDA-1 на I i VIII етапах не виявлено

При порівнянні зразків ЕВК, що зберігались на консерванті CPD зі зразками на CPDA-1, не виявлено статистичної достовірності між змінами, що відбувались на різних етапах зберігання у зазначених консервантах.

Під час виконання досліджень нашу увагу привернули морфологічні зміни еритроцитів в процесі зберігання, що відображені на представлених нижче мікрофотографіях зразків ЕВК.

Як видно з рисунка, під час зберігання ЕВК донорської крові відбуваються зміни морфології еритроцитів. В зразках спостерігались змінені форми, відсотковий вміст яких наведено в таблиці 2.

Мікроскопічне дослідження мазків крові протягом 49 діб зберігання показало зміни форми від нормальних дискоцитів до ехіноцитів і сфероцитів. У дослідженні не спостерігалося значних змін у формі еритроцитів протягом першого тижня зберігання, оскільки нормальні дискоцити домінували. На третьому тижні зберігання ми спостерігали значне збільшення кількості ехіноцитів в обох зразках. Максимальні зміна форми еритроцитів спостерігалася за останніх тижнях зберігання. На останньому, восьмому етапі, відбулось значне збільшення кількості сфероцитів, але в 
Етап зберігання

Перший

Третій

П'ятий

Восьмий
CPDA-1
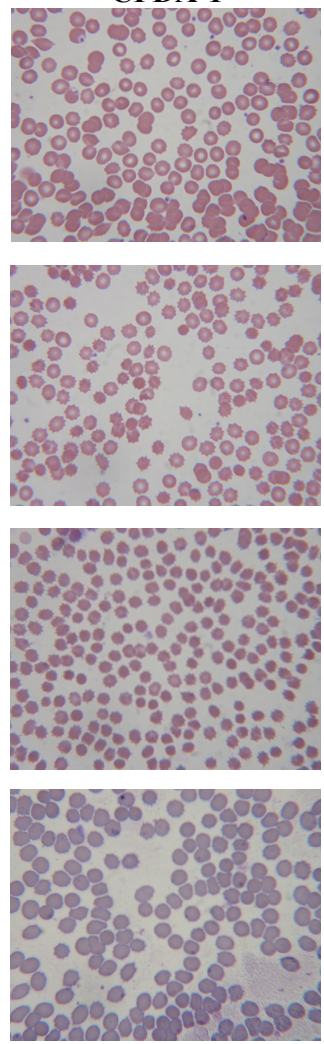

Рисунок. Мікрофотографї еритроцитів на різних етапах гіпотермічного зберігання з розчином CPD і CPDA-1 (×1000)

консерванті CPDA-1 таких клітин було менше, ніж в розчині з консервантом CPD. Можливо, такі відмінності можна пояснити наявністю в консерванті CPDA-1 аденіну, котрий є складовою АТФ, оскільки загальновідомо, що утворення патологічних форм еритроцитів пов'язане 3 характерним для консервованих трансфузійних ЕВК збільшенням рН, зниженням запасів АТФ (Lim H.W.G., et al., цит. по [4]) тощо. Такі форми накопичуються $з$ подовженням терміну зберігання, що підтверджує дані щодо динаміки біомеханічних властивостей мембрани фільтрованих еритроцитів при тривалому гіпотермічному зберіганні [4]. Добре відомо, 


\section{Таблиця 2. Морфологічні зміни еритроцитів (\%)}

\begin{tabular}{|c|l|c|c|c|c|}
\hline $\begin{array}{c}\text { Консервуючий } \\
\text { розчин }\end{array}$ & $\begin{array}{c}\text { Форма } \\
\text { клітин }\end{array}$ & I етап & III етап & VI етап & VIII етап \\
\hline \multirow{4}{*}{ CPD } & Дискоцити & 82,8 & 34,1 & 11,4 & 4,6 \\
\cline { 2 - 6 } & Ехіноцити & 14,6 & 61,3 & 70,7 & 12,2 \\
\cline { 2 - 6 } & Сфероцити & 1,3 & 3,5 & 14,3 & 75,3 \\
\cline { 2 - 6 } & Інші & 1,3 & 1,1 & 3,6 & 7,9 \\
\hline \multirow{4}{*}{ CPDA-1 } & Дискоцити & 85,8 & 34,5 & 6,9 & 5,3 \\
\cline { 2 - 6 } & Ехіноцити & 11,6 & 61,5 & 87,3 & 34,2 \\
\cline { 2 - 6 } & Сфероцити & 1,7 & 2,6 & 3,2 & 45,9 \\
\cline { 2 - 6 } & Інші & 0,83 & 1,4 & 2,6 & 6,4 \\
\hline
\end{tabular}

що подібні ушкодження мембран свідчать про зниження пластичних якостей клітини, іiі стійкості до деформацій [5]. Серед причин нестабільності форми еритроцитів при їхньому зберіганні є здатність втрачати або поглинати рідину та електроліти із консервантів [6]. Збереження форми і розмірів еритроцитів $є$ вкрай важливим для подальшої ефективності трансфузій консервованих ЕВК, в тому числі і для зменшення внутрішньосудинного гемолізу [7, 8]. Іншими біохімічними ознаками патофізіологічних змін еритроцитів при їхньому тривалому зберіганні, що корелюють зі стійкістю мембран еритроцитів, $є$ значна активація процесів окислення [9].

\section{Висновки}

В процесі гіпотермічного зберігання еритроцитвмісних компонентів донорської периферичної крові достовірної різниці в змінах площ еритроцитів не виявлено. Під час гіпотермічного зберігання еритроцитовмісних компонентів протягом 49 діб у консервуючих розчинах CPDA-1 та CPD відбуваються значні зміни форм еритроцитів з нормальних дискоцитів до сфероцитів. Консервуючий розчин, що містив у своєму складі аденін, завдає менше негативного впливу на ЕВК під час їхнього зберігання.

\section{Література}

1. Prudent M., Tissot J. D., Lion, N. In vitro assays and clinical trials in red blood cell aging: Lost in translation. Transfus. Apher. Sci. 2015; 52: 270-6. doi: 10.1016/j.transci.2015. 04.006.

\section{References}

1. Prudent M., Tissot J. D., Lion, N. In vitro assays and clinical trials in red blood cell aging: Lost in translation. Transfus. Apher. Sci. 2015; 52: 270-6. doi: 10.1016/j.transci.2015.04.006. 
2. Hunsicker O., Hessler K., Krannich A., Boemke W., Braicu I., Sehouli J., et al. Duration of storage influences the hemoglobin rising effect of red blood cells in patients undergoing major abdominal surgery. Transfusion. 2018; 1870-80. doi: 10.1111/trf.14627 (online).

3. Collins T. J. Image J for microscopy. BioTechniques. 2007; 43, (1 Suppl): 25-30. doi 10.2144/000112517.

4. Сергунова В.А., Гудкова О.Е., Манченко Е.А., Козлова Е.К., Бобринская И.Г., Черныш А.М. и др. Влияние температуры эритроцитарной взвеси на морфологию и наноструктуру мембран клеток. Общая реаниматология. 2017; 13(4): 30-7. https://doi.org/10.15360/1813-97792017-4-30-37

5. Park H., Lee S., Ji M. Measuring cell surface area and deformability of individual human red blood cells over blood storage using quantitative phase imaging. Sci Rep. 2016; 6:34257.

https://doi.org/10.1038/srep34257

6. Ratull P., Yuyuan Z., Mehdi N., Meghdad R., Yaling L. Quantitative absorption imaging of red blood cells to determine physical and mechanical properties. RSC Adv. 2020; 10(64): 38923-36. doi: 10.1039/d0ra05421f

7. Karon B.S., Hoyer J.D., Stubbs J.R. Changes in band 3 oligomeric state precede cell membrane phospholipid loss during blood bank storage of red blood cells. Transfusion. 2009; 49(7): 1435-42.
2. Hunsicker O., Hessler K., Krannich A., Boemke W., Braicu I., Sehouli J., et al. Duration of storage influences the hemoglobin rising effect of red blood cells in patients undergoing major abdominal surgery. Transfusion. 2018; 1870-80. doi: 10.1111/trf.14627 (online).

3. Collins T. J. ImageJ for microscopy. BioTechniques. 2007; 43, (1 Suppl): 25-30. doi 10.2144/000112517.

4. Sergunova V.A., Gudkova O.E., Manchenko E.A., Kozlova E.K., Bobrinskaya I.G., Chernysh A.M., et al. The Effect of the Erythrocyte Suspension Temperature on the Morphology and Nanostructure of Cell Membranes. General Reanimatology. 2017; 13(4): 30-7 (in Russian) https://doi.org/10.15360/1813-97792017-4-30-37

5. Park H., Lee S., Ji M. Measuring cell surface area and deformability of individual human red blood cells over blood storage using quantitative phase imaging. Sci Rep. 2016; 6: 34257. https://doi.org/10.1038/srep34257

6. Ratull P., Yuyuan Z., Mehdi N., Meghdad R., Yaling L. Quantitative absorption imaging of red blood cells to determine physical and mechanical properties. RSC Adv. 2020; 10(64): 38923-36. doi: 10.1039/d0ra05421f

7. Karon B.S., Hoyer J.D., Stubbs J.R. Changes in band 3 oligomeric state precede cell membrane phospholipid loss during blood bank storage of red blood cells. Transfusion. 2009; 49(7): 1435-42. 
8. Gupta P., Goyal R., Pantola C., Amit S. To Study The Morphological Changes Seen In Stored Blood In A Blood Bank. Journal of Evolution of Medical and Dental Sciences. 2016; 5(77): 5705-9

doi: 10.14260/jemds/ 2016/1287/

9. Аношина М.Ю. Активність перекисного окислення ліпідів як індикатор збереженості еритроцитів пуповинної крові в процесі кріоконсервування / Аношина М.Ю., Калиниченко Т.О. // Гематологія і переливання крові : міжвідомчий збірник. - 2015. - Вип. 38. C. 41-49.

Стаття надійшла 12.08.2021

Контакти: bortnikanna2006@gmail.com
8. Gupta P., Goyal R., Pantola C., Amit S. To Study The Morphological Changes Seen In Stored Blood In A Blood Bank. Journal of Evolution of Medical and Dental Sciences. 2016; 5(77): 5705-9 doi: 10.14260/jemds/ 2016/1287/

9. Anoshina M. Yu., Kalynychenko T. O. The lipid peroxidation activities as an indicator of the red cord blood cell safety during the cryopreservation process. Hematology \& blood transfusion: interdepartamental collection. 2015; 38: 41-9 (in Ukrainian). 